\title{
Habitat preferences influencing populations, distribution and conservation of the endangered saproxylic beetle Cucujus cinnaberinus (Coleoptera: Cucujidae) at the landscape level
}

\author{
JAKUB HORÁK ${ }^{1,2}$, Eva VÁVROVÁ ${ }^{1}$ and KaREL CHOBOT $^{3}$ \\ ${ }^{1}$ Department of Biodiversity Indicators, Silva Tarouca Research Institute for Landscape and Ornamental Gardening, Květnové \\ náměstí 391, CZ-252 43 Průhonice, Czech Republic; e-mail: jakub.sruby@seznam.cz \\ ${ }^{2}$ Department of Ecology, Faculty of Environmental Sciences, Czech University of Life Sciences in Prague, Kamýcká 1176, \\ CZ-165 21 Prague 6, Czech Republic \\ ${ }^{3}$ Agency for Nature Conservation and Landscape Protection of the Czech Republic, Nuselská 39, CZ-140 00 Prague 4, \\ Czech Republic
}

Key words. Coleoptera, Cucujidae, Cucujus cinnaberinus, dead wood, fragmentation, Natura 2000, man-made habitats, conservation

\begin{abstract}
Cucujus cinnaberinus (Scopoli, 1763) is a saproxylic beetle listed in the IUCN Red List and the European Habitats Directive. Although the species is highly protected and often red-listed little is known about its ecological requirements and status of its populations. Therefore, our main aims were to review its current and historical distributions and status of C. cinnaberinus populations in Europe and to determine its recent habitat preferences at the landscape level in the Czech Republic, where the increasing number of records over the last few years indicates a possible increase in abundance of this beetle. Cucujus cinnaberinus is closely associated with soft-wood and broad leaved trees and is able to colonize man-made habitats from persisting local populations if there is a sufficient supply of suitable dead wood. This beetle is not restricted to old-growth forests or even relict woodland, as previously reported, but currently predominantly inhabits abandoned planted stands of trees like lignicultures or avenues, which have an open canopy. Colonization of stands dominated by hybrid poplars probably resulted in the recent increase in the number of records of this species in the central European countries. However, this could present problems for the protection of this species in future, because the trees in these stands are gradually dying and are not being replaced. The decline and extinction of $C$. cinnaberinus on the northern and southern edges of its distribution was probably caused by the absence of soft-wooded broadleaved trees in intensively managed forests and other more suitable habitats.
\end{abstract}

\section{INTRODUCTION}

Cucujus cinnaberinus is a saproxylic beetle with a European distribution (Horák et al., 2008). This beetle is one of the protected species explicitly named in Annexes II and IV of the EU Habitats Directive with the goal of maintaining existing populations and ensuring its longterm survival (CEEC, 1992). Furthermore, C. cinnaberinus is classified as vulnerable in the IUCN Red List of Threatened Species (Baillie \& Groombridge, 1996) and is also cited in many national Red lists throughout Europe (Geiser, 1998; Šternbergs, 1998; Holecová \& Franc, 2001; Rassi et al., 2001; Pawłowski et al., 2002; Gärdenfors, 2005; Jelínek, 2005; Kålås et al., 2006).

Saproxylic species are dependent at some stage in their life cycle on the wood of moribund or dead trees, woodinhabiting fungi or the presence of other saproxylics (Speight, 1989). In general the amount of dead wood, in particular decaying large diameter tree trunks, is often high in old-growth forests but rare or nonexistent in managed forests (Siitonen \& Saaristo, 2000; Ranius, 2001). In central Europe, where forest management is intensive, large quantities of dead wood only occur, for example, after natural disturbances such as windstorms, but salvage logging of all fallen and broken dead wood greatly reduces the availability of this wood for the saproxylic fauna (Lindenmayer et al., 2004; Jonášová \& Prach, 2008).

Large-scale intensive forest management and changes in landscape structure have resulted in a marked decrease in the abundance of old trees and led to a decline in suitable primary habitats for saproxylic organisms. As a consequence, a sharp decline in the number of populations and population sizes of many saproxylic species has been recorded over the past century. There are studies indicating that the loss of primary habitats causes the loss of more remarkable groups, such as large mammals or birds, even though these groups are more mobile (e.g., Michalski \& Peres, 2007). Such is the plight of invertebrates. Some relict species that are dependent on the continuity of forests, such as some curculionids or carabids, have become locally extinct and are not able to recolonize secondary (even if naturally regenerated) forest stands (Wiezik et al., 2007; Spitzer et al., 2008). On the other hand, some threatened species have been able to adapt to environmental changes and colonize man-made habitats that have similar microhabitat conditions to their natural primary habitats. Such habitats include hunting forests, city parks, avenues or solitary trees in agricultural landscapes or along streams (Horion, 1960). Authors also 


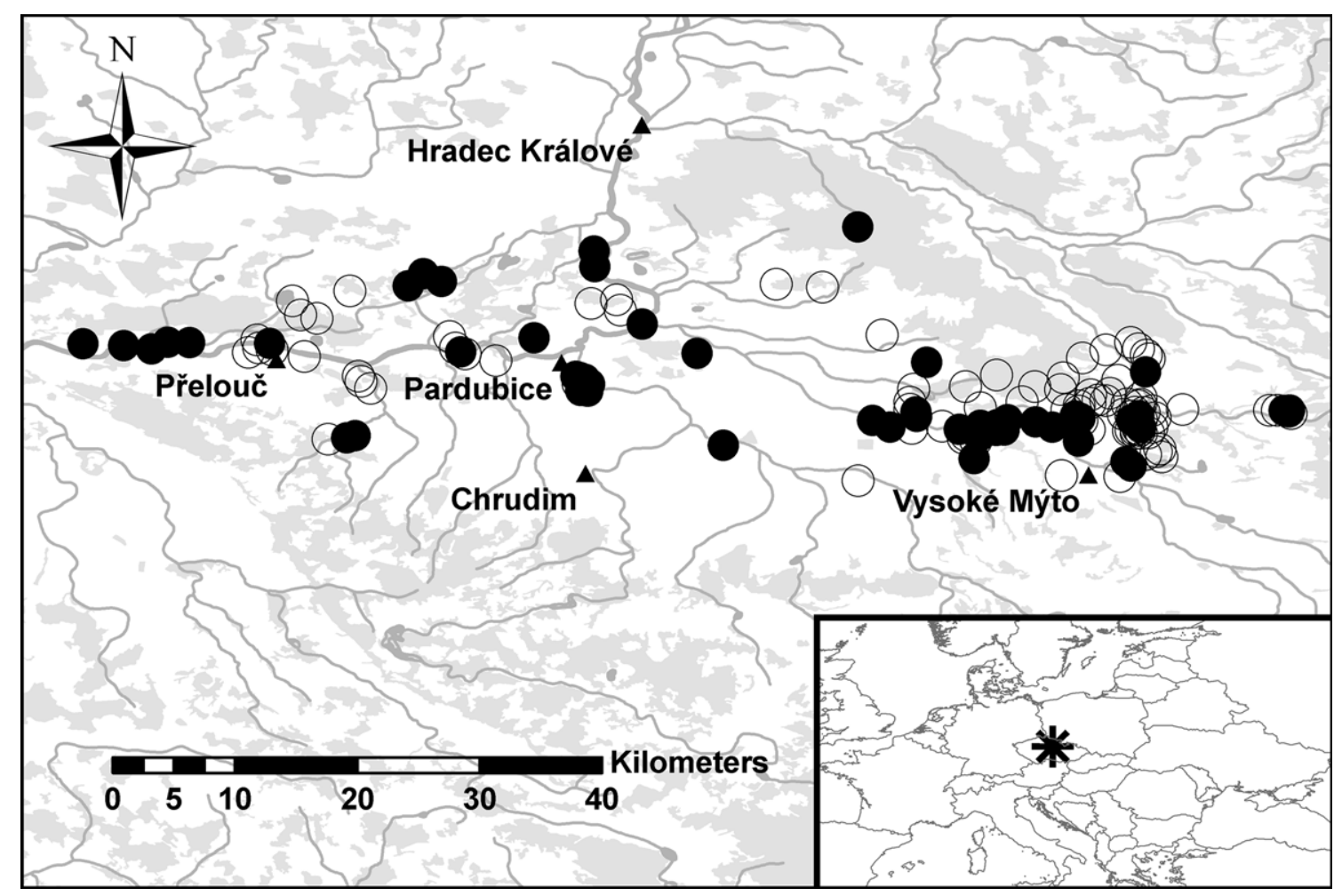

Fig. 1. Location of the study sites; presence of Cucujus cinnaberinus is indicated by full circles, absence by empty circles, rivers, lakes and ponds are dark grey and forest land light grey, location of large cities are indicated by triangles. An asterisk indicates the location of this study area in Europe.

mention an association with such traditional management as coppicing or pollarding (Kletečka \& Kollar, 2003; Ranius et al., 2005).

Some authors (Roubal, 1936; Bílý, 1990) indicate that C. cinnaberinus is a rare forest or even relict species. Most records of the habitat preferences of this species published before the end of $20^{\text {th }}$ century referred to undisturbed primeval forests (Palm, 1941; Speight, 1989; Eriksson, 2000). However, based on several recent papers, it appears that the abundance and distribution of C. cinnaberinus may have increased recently (Bussler, 2002; Mocek, 2007; Schlaghamerský et al., 2008). Even though $C$. cinnaberinus is highly protected and often redlisted, its populations and habitat requirements are not well documented.

The first aim of the present paper was to compile data on the occurrence of $C$. cinnaberinus and determine its current distribution and abundance in Europe. The second aim was to determine the current preferred habitats of $C$. cinnaberinus at the landscape level in central Europe, where increasing number of records of this beetle over the last few years indicates it is possibly spreading. Our hypothesis was that the recent increase in the number of records of $C$. cinnaberinus has resulted from this beetle adapting to other habitats in the intensively exploited landscape.

\section{MATERIAL AND METHODS}

Review of the distribution of $C$. cinnaberinus in Europe with emphasis on the Czech Republic

Records of C. cinnaberinus occurrence presented in this study were obtained by evaluation and comparison of several data sources (e.g., published records or personal communications). C. cinnaberinus was described and included in the Linnaean system by Scopoli (1763), but records from the $18^{\text {th }}$ and $19^{\text {th }}$ centuries are scarce and incomplete. Therefore, only records from the period 1898-2007 were included in this review. Data concerning the distribution of $C$. cinnaberinus in the Czech Republic were extracted mainly from an interactive public mapping survey of this species on BioLib (Chobot \& Horák, 2009).

\section{Study area and sampling strategy}

The study area is located in the eastern part of Polabí lowland, where one of the largest populations of C. cinnaberinus occurs in the Czech Republic. This area covers more than $1000 \mathrm{~km}^{2}$ and is covered mainly by agricultural land and intensively managed forests with remnants of old-growth or noncommercial stands. In the past it was almost completely covered by floodplain forests. This research was carried out from autumn 2006 to autumn 2008.

The current occurrence of $C$. cinnaberinus was determined by studying 151 sites (Fig. 1) in the study area, which were selected as representative of the various potential habitats of this beetle. The presence of dead wood suitable for the genus $\mathrm{Cucu}$ $j u s$, i.e. dead standing or lying trees, or parts of trees in an intermediate stage of decay (Palm, 1941; Bussler, 2002), was the only requisite condition for establishing a study site. The intermediate stage of decay is that when the primary phloeoxylophages have already left the wood, but the bark is still present. The area of the study sites depended on the area of the forest 
stands. The study site covered the whole stand in the case of stands smaller than 5 ha, in larger stands the area of a study site was 5 ha and situated in a representative part of the stand. The suitable dead wood was checked for larvae, pupae, adults and fragments (red wing-cases of adults or amber-coloured parts of larval exuvia) by sampling strips of bark. One strip of bark (approximately $0.30 \times 0.30 \mathrm{~m}$ ) was peeled randomly from the trunk of each tree and replaced after collecting the data. If necessary, e.g., on the underside of a lying trunk of a tree, the bark was reattached to the trunk with nails. Data collecting ceased when either at least one specimen was found (species presence) or all suitable and accessible dead wood at the site was inspected without finding evidence of the presence of this species (species absence). We determined the larvae in the field using Mamaev et al. (1977). Voucher specimens were not collected.

\section{Habitat characteristics}

At each study site, three habitat characteristics, i.e. character and usage of the stand, stand arrangement and stand isolation, were recorded and surveyed for predictor variables in statistical analyses evaluating the habitat preferences of $C$. cinnaberinus at the landscape level. The terms primary and secondary stand are used according to Corlett (1994). Primary stands are those that have existed since the 1760 's. This information was derived from Austrian imperial military maps (see Boukal, 2008). A stand could be occasionally disturbed but never completely deforested.

The following six categories of stand character and usage were distinguished: (i) Forest reserve - primary old-growth forest left to natural processes with relatively large quantities of dead wood, (ii) Forest remnant - the same as a reserve but smaller in area $(<5$ ha), (iii) Riparian stand - secondary noncommercial stand situated along a river or in its floodplain, often with quantities of dead wood (only trees believed to be dangerous for visitors are removed), (iv) Windbreak - secondary non-commercial stand planted as a protection against soil erosion, almost completely neglected by people and sometimes with large quantities of dead wood, (v) Ligniculture - secondary stand dominated by poplar hybrids with a short rotation period and planted in open canopy in floodplains of central Europe during the period from 1950's to 1970's as a protection against soil erosion and to provide a quick source of timber. However, as these fast-growing and short-lived poplar hybrids have recently not been utilized by the timber industry and are dying, these stands are characterized by large quantities of dead wood. (vi) Commercial forest - intensively managed and exploited secondary stands generally characterized by the lack of dead wood.

The arrangement of the trees in the stands was classified in the following way: (i) line stands, (ii) small compact stands situated in an open landscape or in commercial forest plantations, but not exceeding 5 ha, (iii) large compact stands - larger than 5 ha.

The isolation of the stands was clasified based on the distance to the nearest forest larger than 5 ha. Connected stands were parts of a forest or closer than $1 \mathrm{~km}$ to a forest, the isolated ones were situated more than $1 \mathrm{~km}$ from the nearest forest.

The characteristics of suitable dead wood (i.e. dead wood having the qualities known to be necessary for genus Cucujus; see above) present in the studied stands were recorded. The dead wood was classified in following categories: (i) introduced or native, (ii) broadleaved or coniferous and (iii) soft-wooded (not only conifers, but also the genera Populus, Salix, Tilia, Aesculus and Alnus) or hard-wooded. If the evaluation was not unambiguous, for example if there was dead wood of both broadleaved and coniferous trees present in the studied stand the characteristics of the prevailing dead wood were recorded. (Note: The classification refers to the dead wood present in the stands and may not be representative of the trees in the stand).

\section{Data processing}

Statistical analyses evaluating the habitat preferences of $C$. cinnaberinus at the landscape level were carried out using Statistica 8. The presence or absence of the species was the response variable and binary coded as either 1 or 0 . A generalised linear model (GLZ), with a binomial distribution of the response variable and Logit link function, was used for this analysis (Hill \& Lewicki, 2007). This method is equivalent to Logistic regression, which is commonly used in conservation biology to estimate occurrence probabilities in relation to predictors.

First of all, the results were tested for spatial autocorrelation, because spatially autocorrelated results may pose problems for traditional significance tests due to violations of the assumption of independence (e.g., Legendre, 1993). The spatial correlation structure of the results was modelled as a combination of the spatial coordinates, i.e. latitude $(\mathrm{X})$ and longitude $(\mathrm{Y})$, their second-order polynomial functions $\left(\mathrm{X}^{\wedge} 2, \mathrm{Y}^{\wedge} 2\right)$ and their interactions $\left(X^{*} Y, X^{*} Y^{\wedge} 2, Y^{*} X^{\wedge} 2, X^{\wedge} 2 * Y^{\wedge} 2\right)$. These variables were included in a GLZ selection process and a minimum adequate model was identified using backward stepwise selection. The resulting combination was included in the GLZ selection procedure with the predictors of interest.

The potential predictor variables of interest, i.e. stand character and usage, stand arrangement and stand isolation, were first assessed for significance in univariate analyses and then a model selection procedure with backward stepwise selection of predictors was used to create a multivariate model. Characteristics of the suitable dead wood present in the stands were tested separately by univariate analyses.

\section{RESULTS}

\section{Distribution and abundance of $C$. cinnaberinus in European countries}

Populations of $C$. cinnaberinus seem to be stable in central European countries. Austria, the Czech Republic, Germany (Bayern), Hungary, Poland (Śląsk and Białowieża) and Slovakia were identified as current hotspots in the distribution of C. cinnaberinus. The situation in Scandinavia (Finland, Norway and Sweden), the Baltic region (Estonia, Latvia and Lithuania), Spain and Italy is less favourable. The populations of this species in these countries are declining or extinct. The status of the populations in Belarus, Moldova, Romania, the Russian Federation and Ukraine is unknown. Nevertheless, these populations could be greater than indicated due to the presence of suitable habitats. The status of $C$. cinnaberinus populations in Bosnia and Herzegovina, Bulgaria, Croatia and Serbia, where the species occurred in the past, but for which there are no recent records, is very uncertain. The situation is probably similar in Albania, Greece, Kosovo, Macedonia and Montenegro, for which there are no records (this species may have been extinct there due to loss of habitats before the presence of this beetle is likely to have been recorded), or in France, for which there are no confirmed records (Fig. 2). 


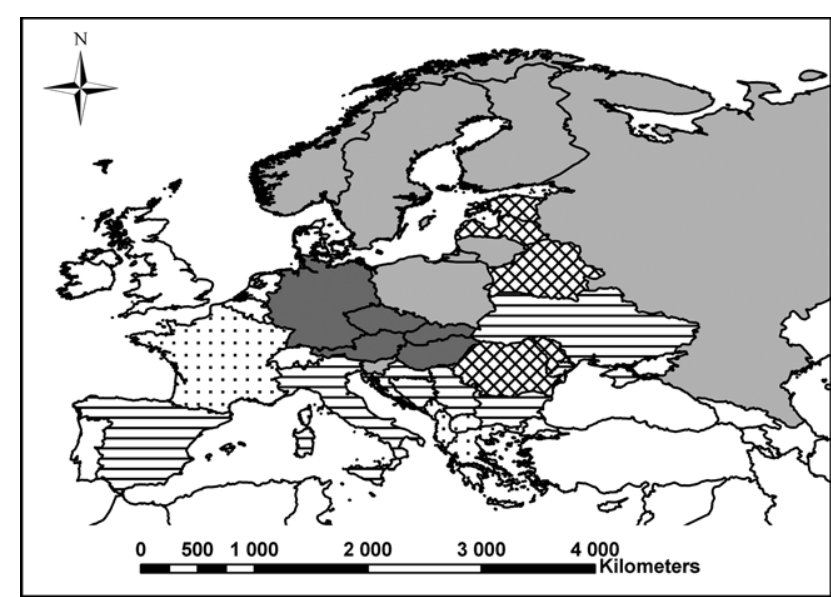

Fig. 2. Distribution and status of Cucujus cinnaberinus populations in European countries based on the number of records reported since 2000, more than 50 sites (dark grey); 5-20 sites (light grey); less than 5 sites (crosshatch); based on records for the period 1950-1999, less than 5 sites (simple hatch); possible occurrence (stipple).

\section{Historical vs. recent occurrence of $C$. cinnaberinus in the Czech Republic}

The survey of the historical and recent occurrence of $C$. cinnaberinus in the Czech Republic revealed a considerable increase in the number of records over the last decades. The sharpest increase in the number and sizes of the populations was recorded in the period between 1998 and 2007, when the number of records was more than ten times higher than in the previous period, i.e. 1988-1997 (Fig. 3).

\section{Habitat preferences of $C$. cinnaberinus at the landscape level}

C. cinnaberinus was present at 60 of the 151 sites surveyed in the study area. Fig. 4 illustrates the proportion of presences and absences of $C$. cinnaberinus in the various types of stand defined in terms of stand character and usage, arrangement and isolation. The numbers on the columns indicate the number of presences and absences.

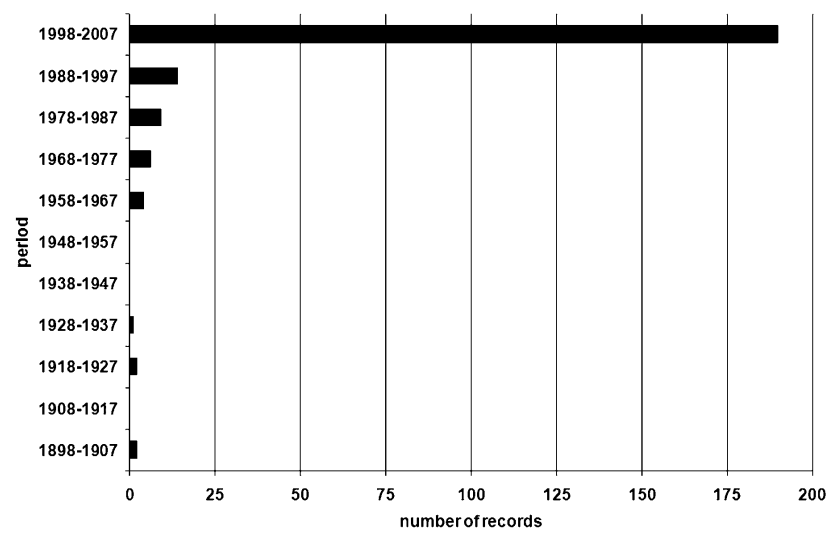

Fig. 3. The number of records of the occurrence of Cucujus cinnaberinus in the Czech Republic reported during the course of the last century.

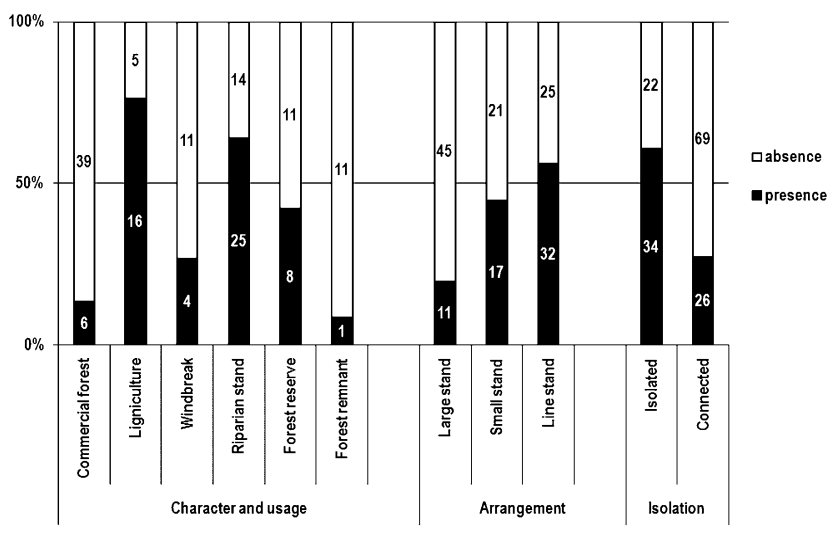

Fig. 4. Habitat preferences of Cucujus cinnaberinus at the landscape level.

Results of the test for spatial autocorrelation did not show any substantial violations of the assumption of independence. Only the X coordinate had a significant effect on the occurrence probability of the beetle at the 5\% significance level $(P=0.0346)$. However, when it was included in the models together with our predictors of interest, the effect of the $\mathrm{X}$ coordinate was not significant at the $5 \%$ significance level, whereas the effect of the predictors remained highly significant. Thus, only the results with predictors of interest are presented.

Results of the statistical analyses of the habitat preferences of $C$. cinnaberinus at the landscape level showed the significant effect of the character and usage of the stand (Wald Stat. $=33.42 ; P=0.0000$ ) on the occurrence of this species in the study area. Lignicultures and riparian stands were found to have significantly higher probabilities of $C$. cinnaberinus occurrence, whereas commercial forests and forest remnants were less likely to be colonized by this species (Table 1).

Differences in the probability of $C$. cinnaberinus occuring in habitats defined in terms of stand arrangement (Wald Stat. $=15.09 ; P=0.0005$ ) and isolation (Wald Stat. $=15.58 ; P=0.0001$ ) were also significant. The line stands were more likely to be inhabited by $C$. cinnaberinus than both small and large forests, and isolated stands than connected ones (Table 1).

The final multivariate model, after stepwise selection of predictor variables, reveals that only two predictor variables had a strong effect on the occurrence probability of C. cinnaberinus in the study area, i.e. stand character and usage, and stand arrangement. This species was significantly more likely to inhabit line stands and lignicultures. Stand isolation was removed in the stepwise model selection process (Table 1).

Our results confirmed the dependence of $C$. cinnaberinus occurrence on the following dead wood characteristics: tree species origin (Wald Stat. $=28.53 ; P<10^{-6}$ ), wood hardness (Wald Stat. $=9.42 ; P=0.0022$ ) and coniferous or broadleaved trees (Wald Stat. $=5.50 ; P=$ 0.0191 ) at the $5 \%$ level of significance. C. cinnaberinus mainly preferred poplar (Populus spp.) like trees (Fig. 5). 
TABLE 1. Results of statistical analyses of differences in the probability of Cucujus cinnaberinus occurring in habitats defined in terms of stand character and usage, arrangement and isolation.

\begin{tabular}{|c|c|c|c|c|}
\hline Predictor variable & Category & $\begin{array}{c}\text { Regression coefficient } \\
\text { estimate }\end{array}$ & Wald Stat. & $\mathrm{P}$ \\
\hline \multicolumn{5}{|c|}{ Models with a single predictor variable } \\
\hline \multirow{7}{*}{ Character and usage } & Intercept & -0.643 & 6.72 & 0.0095 \\
\hline & Commercial forest & -1.229 & 7.96 & 0.0048 \\
\hline & Forest remnant & -1.755 & 3.91 & 0.0481 \\
\hline & Ligniculture & 1.806 & 13.79 & 0.0002 \\
\hline & Riparian stand & 1.223 & 11.01 & 0.0009 \\
\hline & Forest reserve & 0.324 & 0.51 & 0.4742 \\
\hline & Windbreak & -0.369 & 0.47 & 0.4925 \\
\hline \multirow{4}{*}{ Arrangement } & Intercept & -0.458 & 6.48 & 0.0109 \\
\hline & Large stand & -0.951 & 12.92 & 0.0003 \\
\hline & Small stand & 0.246 & 0.90 & 0.3439 \\
\hline & Line stand & 0.705 & 8.86 & 0.0029 \\
\hline \multirow{3}{*}{ Isolation } & Intercept & -0.270 & 2.29 & 0.1305 \\
\hline & Isolated & 0.706 & 15.58 & 0.0001 \\
\hline & Connected & -0.706 & 15.58 & 0.0001 \\
\hline \multicolumn{5}{|c|}{ Model after stepwise selection of predictor variables } \\
\hline \multirow{7}{*}{ Character and usage } & Intercept & -0.753 & 8.05 & 0.0046 \\
\hline & Commercial forest & -0.986 & 3,39 & 0.0656 \\
\hline & Forest remnant & -1.518 & 2.58 & 0.1081 \\
\hline & Ligniculture & 2.599 & 10.90 & 0.0010 \\
\hline & Riparian stand & 0.362 & 0.55 & 0.4577 \\
\hline & Forest reserve & 0.856 & 2.00 & 0.1576 \\
\hline & Windbreak & -1.314 & 4.09 & 0.0432 \\
\hline \multirow{3}{*}{ Arrangement } & Large stand & -0.478 & 1.04 & 0.3079 \\
\hline & Small stand & -0.736 & 1.61 & 0.2050 \\
\hline & Line stand & 1.214 & 7.31 & 0.0069 \\
\hline
\end{tabular}

\section{DISCUSSION}

\section{Distribution and status of $C$. cinnaberinus populations in Europe}

Our review of the recent and historical distributions of C. cinnaberinus in Europe revealed the presence of relatively strong populations of this species in central Europe. In contrast, a sharp decline in the number and sizes of the populations has probably occurred on the northern and southern edges of its distribution over the past century. In northern Europe $C$. cinnaberinus was widespread in Finland (Saalas, 1926; cited in Palm, 1941) and common in some parts of Sweden in the first half of the $20^{\text {th }}$ century

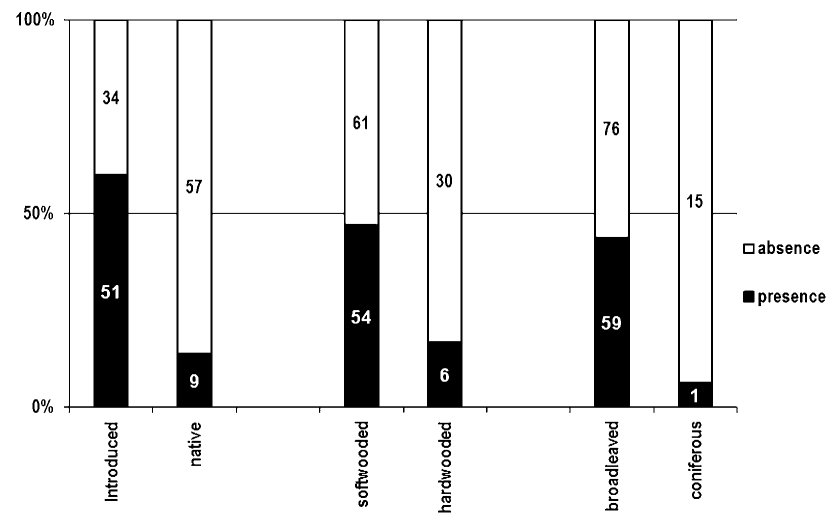

Fig. 5. Occurrence of Cucujus cinnaberinus expressed in terms of the characteristics of the dead wood.
(Palm, 1941). However, currently C. cinnaberinus is a threatened and red-listed species throughout Scandinavia (Rassi et al., 2001; Gärdenfors, 2005; Kålås et al., 2006). For instance, in Sweden it is now probably only present along the banks of the river Dalälven (Eriksson, 2000). A similar decline was recorded in the Baltic republics (Süda \& Voolma, 2005) and in parts of Poland, where most records are for the period from the second half of the $19^{\text {th }}$ century to the first half of the $20^{\text {th }}$ century, and it is most abundant in the Białowieża primeval forest (Kubisz, 2004). The situation in the countries on the southern edge of its distribution is even worse. There are no recent records from Italy (E. Ratti, pers. comm.) and Spain (M. Mendéz, pers. comm.) and C. cinnaberinus is probably extinct there. The only known population in the region of former Yugoslavia probably persists in Slovenia (Pirnat \& Drovenik, 2004).

The distribution and population status of $C$. cinnaberinus in eastern part of Europe are not clear because precise records are scarce and knowledge of the fauna relatively poor. Even so, the populations there seem to be stable (A.A. Zaitsev, pers. comm.) and recent studies even suggest that $C$. cinnaberinus may be relatively common in this area (Siitonen \& Martikainen, 1994; Bussler et al., 2005).

\section{Habitat preferences}

C. cinnaberinus is considered to be a typical forest or relict species occurring predominantly in undisturbed (Bílý, 1990), close-to-natural and virgin (Eriksson, 2000) 
or primeval (Palm, 1941; Speight, 1989; Kubisz, 2004) forests. However, the results presented here indicate that current strongholds of $C$. cinnaberinus in the Czech Republic are predominantly lignicultures and riparian stands, whereas remnants of old-growth forests and commercial forests were less likely to be colonized. Lignicultures and riparian stands are typical secondary habitats, which are similar in terms of a tree species composition dominated by poplars and the presence of relatively large amounts of dead wood. Despite being established for producing timber there is often relatively large amounts of dead wood in lignicultures (e.g., after high winds) due to the commercial unattractiveness of poplar wood, which is soft and often rotten and inaccessible at waterlogged sites (Horák \& Adamová, 2009).

The stands of poplar hybrids were planted also in other central European countries, e.g., Slovakia, southern Germany, Austria and Hungary over the same period. Their occurrence corresponds well with the hotspots in the recent distribution of $C$. cinnaberinus in Europe. In areas with intensively managed forests, where there are no withered poplar hybrid lignicultures, the species has most likely declined or is now extinct (Scandinavia and southern Europe). Poplar hybrids were also planted in northern Italy, but there are no records of $C$. cinnaberinus occuring in this region (E. Ratti, pers. comm.), probably because it is isolated from central European populations.

The suggestion that this species requires undisturbed close-to-nature forest stands is not supported by the presence of relatively strong populations of this beetle close to large cities (e.g., Pardubice) in the study area. Horion (1960) also cites records of this species in large cities in the middle of the $19^{\text {th }}$ century.

All these findings support the hypothesis that the availability of new habitats that provide conditions similar to those in primary natural habitats, i.e. especially a sufficient quantity of suitable dead wood, could be one of the reasons for the recent increase in the number of records of C. cinnaberinus in central Europe. The dying poplar plantations may simulate the later phases of pioneer forest succession.

Our results also indicate that fragmentation of formerly continuous habitats due to human activity has probably not been the main cause of the decline in the abundance of $C$. cinnaberinus. This beetle seems to be able to colonize isolated habitats from persisting local populations if there is sufficient quantity of suitable dead wood in the habitat and it has the other requirements of saproxylic beetles (e.g., Vodka et al., 2009). The greater preference for open line stands than closed forests could indicate that the activity and development of this species is very dependent on exposure to sun. Thus, we hypothesize that C. cinnaberinus, like many other saproxylic beetles, requires more open canopy habitats with large quantities of dead wood, which is warmer as a result of being exposed to the sun (Jonsell et al., 1998; SverdrupThygeson \& Ims, 2002; Hyvärinen et al., 2006; Franc \& Götmark, 2008; Vodka et al., 2009).
The key finding in terms of $C$. cinnaberinus conservation is that this species seems to be closely associated with soft-wooded broadleaved trees. This conforms with the observations of Bussler (2002) who notes that $C$. cinnaberinus prefers lowland forests or partly mixed mountain forests, which include a higher proportion of deciduous trees. Although these trees are the habitats of many endangered species of insect (Sverdrup-Thygeson \& Ims, 2002; Lindhe \& Lindelöw, 2004), they have been and still are selectively cut from commercial stands before maturity, because they have little value as timber trees. Such forest management practises together with the little importance attached to the natural succession of pioneer trees, shortage of natural willow-poplar alluvial lowland forests, which were mostly drained and clear-felled, as well as a general shortage of line stands with old trees have probably led to a decrease in the availability of suitable habitats for this species.

\section{Increasing numbers of records of $C$. cinnaberinus in the Czech Republic}

The considerable increase in the number of records of this species occurring in the Czech Republic over the last decades suggests that $C$. cinnaberinus is possibly spreading in this region. We are aware that the number of records could be affected by the different intensity of research during the evaluated period (Konvička \& Beneš, 2005), which may have resulted from the increase in surveys associated with the listing of species in several conservation documents (e.g., IUCN Red List of Threatened Species, Habitats Directive 92/43/EEC, Natura 2000). However, the marked preference of $C$. cinnaberinus for lignicultures, i.e. open canopy secondary stands dominated by short lived poplar hybrids planted on floodplains in central Europe from the 1950's to 1970's, and the coincidence of the dying of the trees in these stands with the increase in the number of the records of this species, provides strong support for the idea that $C$. cinnaberinus is spreading because it has adapted to exploit this habitat.

\section{Implications for conservation - Poplars: a Trojan horse or an opportunity?}

C. cinnaberinus is threatened by intensive forest management, which results in a closed canopy, changes in tree composition, selective cutting of old moribund softwooded trees and removal of dead wood after natural disturbances, as well as a general shortage of line stands consisting of old soft-wooded trees in the landscape. Prolonged storage of timber in forests can also represent a problem, because beetles lay eggs in the logs, which are lost when the timber is processed.

Currently in the Czech Republic, C. cinnaberinus is found only occasionally in traditional forest habitats, but more frequently in poplar lignicultures and riparian stands. Unfortunately, poplar lignicultures are short-lived and were planted over a relatively short period. Nowadays these stands are gradually dying and are not being replanted (Horák, 2007), which could result in a decline in the abundance of $C$. cinnaberinus in the near future. 


\section{Strategies for management}

The habitat requirements of the larvae and adults of $C$. cinnaberinus are relatively similar, thus the protection of this species is easier than that of other saproxylic beetles, such as longhorn beetles (Cerambycidae) or rose chafers (Cetoniidae), which are in many cases floricolous as adults. It is possible to protect invertebrates, but only if the landscape is a mosaic of spatially and temporally heterogeneous patches (e.g., Baum et al., 2004).

Good management practices include the planting of heterogeneous avenues or open-canopy stands with softwooded broadleaved trees, such as poplars or willows. It is not necessary to continue planting poplar hybrids, even if this seems to be the simplest solution. However, such management could replace the former traditional or closeto-natural forest management based on wood pasturing, natural disturbances, such as fires needed for the regeneration of aspens or floods needed for the regeneration of white and black poplars, and provide stands of noncommercial soft-wooded species of trees that contain some dying trees. If not, many of the threatened saproxylic species will disappear from the forests, and the last refuge for them will be in non-commercial forests and trees growing in an open landscape. Windstorms, floods and beavers can also act as natural managers and by their action provide favourable habitats for saproxylic beetles.

ACKNOWLEDGEMENTS. We would like to thank M. Boukal for many interesting ideas and assistance in the field, and V. Kubán̆ and P. Švácha for providing literature. We thank V. Franc, A.A. Zaitsev, A. Sedláček, J. Mertlik, M. Mikát, B. Mocek, A. Sverdrup-Thygeson, E. Ratti, M. Mendéz, Z. Kletečka, K.N.A. Alexander and J. Vávra for contributing information and L. Čížek and M. Škorpík for fruitful discussions. We also thank J. Horáková, M. Andreas, J. Růžička, V. Kalina, J. Klápště, O. Zicha, Š. Pechánková and P. Zasadil. The comments of an anonymous referee and M. Konvička greatly helped to improve the manuscript. Since $C$. cinnaberinus is protected by Czech law, our research was dependent on receiving a permit from the Agency for Nature Conservation and Landscape Protection of the Czech Republic. This study was partly supported by a grant from CIGA ČZU no. 42110/1313/3112 "Spatial and temporal distribution of development stages of saproxylic beetles" and the CZ Ministry of Environment, No. MSM 6293359101 .

\section{REFERENCES}

Baillie J. \& Groombridge B. 1996: IUCN Red List of Threatened Animals. The IUCN Species Survival Commission, Gland, Switzerland, $286 \mathrm{pp}$.

Baum K.A., Haynes K.J., Dillemuth F.P. \& Cronin J.T. 2004: The matrix enhances the effectivness of corridors and stepping stones. Ecology 85: 2671-2676.

BílÝ S. 1990: Cucujus cinnaberinus Scopoli, 1763, Cucujidae. In Anonymous (ed.): Beetles. Artia, Prague, pp. 142-143.

BouKal M. 2008: Fragmentation of the landscape and continuity indicating species. In Horák J. (ed.): Beetles Associated with Trees. Pardubický kraj \& ČLS (Pardubice Region \& Czech Forest Society), Pardubice, pp. 4-8 [in Czech, English abstr.]. Available on: $<$ http://www.elateridae.com/page.php?idcl= 95>.
BussLer H. 2002: Untersuchen zur Faunistik und Ökologie von Cucujus cinnaberinus (Scop., 1793) in Bayern (Coleoptera: Cucujidae). Nachr. Bayer. Entomol. 51: 42-60.

Bussler H., Müller J. \& Dorka V. 2005: European natural heritage: the saproxylic beetles in the proposed Parcul National Defileul Jiului. Anal. Inst. Cerc. Amen. Silvice 48: $55-71$.

CECC 1992: Directive 92/43/EEC of 21 May 1992 on the Conservation of Natural Habitats and of Wild Fauna and Flora. Available on: $<$ http://eur-lex.europa.eu/>.

Сновот K. \& НовÁк J. 2009: Map of distribution of Cucujus cinnaberinus in Czech republic. In Zicha O. (ed.): Biological Library - BioLib. Avilable on: <http://www.biolib.cz/en/ taxonmap/id126/>.

CoRlett R.T. 1994: What is secondary forest? J. Trop. Ecol. 10: 445-447.

ERIKSSON P. 2000: Long term variation in population densities of saproxylic Coleoptera species at the river of Dalalven, Sweden. Entomol. Tidskr. 121: 119-135 [in Swedish, English abstr.].

Franc N. \& Götmark F. 2008: Openness in management: Hands-off vs partial cutting in conservation forests, and the response of beetles. Biol. Conserv. 141: 2310-2321.

GÄRDENFORS U. 2005: Rödlistade arter $i$ Sverige 2005 - The 2005 Red List of Swedish Species. ArtDatbanken, SLU, Uppsala. Avilable on: $<$ http:// www.artdata.slu.se>.

Geiser R. 1998: Rote Listen der Käfer (Coleoptera). In Binot M., Bless R., Boye P., Gruttke H. \& Pretscher P. (eds): Rote Liste gefährdeter Tiere Deutschlands. Vol. 55. Schriftenreihe Landschaftspflege Naturschutz, Bonn, Bad Godesberg, pp. $168-230$.

Hill T. \& Lewicki P. 2007: Statistics Methods and Applications. StatSoft, Tulsa, OK.

Holecová M. \& Franc V. 2001: Red list of plants and animals of Slovakia. Ochrana Prirody 20: 111-128 [in Slovak].

HorÁk J. 2007: Poplars as host wood plants of the Flat bark beetle (Cucujus cinnaberinus) (Coleoptera: Cucujidae). In Dreslerová J. \& Packová P. (eds): Endangered Wood Plants of the Czech Republic-Geobiocenological Writings. Vol. 12. LDF MZLU, Brno, pp. 83-90 [in Czech, English abstr.].

HorÁK J. \& AdAmovÁ J. 2009: Contribution to knowledge of two rare saproxylic beetles (Coleoptera) from Eastern Bohemia (Czech Republic). Elateridarium 3: 7-18. Available on: $\quad<$ http://www.elateridae.com/elateridarium/index.php? numb $=4>$.

Horák J., Сновот K., KohutKa A. \& Gebauer R. 2008: Possible factors influencing the distribution of a threatened saproxylic beetle Cucujus cinnaberinus (Scopoli, 1763) (Coleoptera: Cucujidae). Coleopt. Bull. 62: 437-440.

Horion A. 1960: Faunistik der mitteleuropäischen Käfer. Band VII. Clavicornia 1. Teil (Sphaeritidae bis Phalacridae). A. Feyel, Überlingen-Bodensee, 346 pp.

Hyvärinen E., Kouki J. \& Martikainen P. 2006: Fire and greentree retention in conservation of red-listed and rare deadwood-dependent beetles in Finish boreal forests. Conserv. Biol. 20: 1711-1719.

JeLíneK J. 2005: Cucujidae. In Farkač J., Král D. \& Škorpík M. (eds): Red List of Threatened Species in the Czech Republic. Invertebrates. Agentura ochrany př́rody a krajiny ČR (Agency for Nature Conservation and Landscape Protection of the Czech Republic), Praha, pp. 492-493.

JonÁŠOVÁ M. \& PRACH K. 2008: The influence of bark beetles outbreak vs. salvage logging on ground layer vegetation in Central European mountain spruce forests. Biol. Conserv. 141: $1525-1535$. 
Jonsell M., Weslien J. \& Ehnström B. 1998: Substrate requirements of red-listed saproxylic invertebrates in Sweden. Biodiv. Conserv. 7: 749-764.

KÅLÅs J.A., VIKEN Å. \& BAKKEN T. 2006: Norsk Rødliste 2006 Norwegian Red List. Artsdatabanken, Norway, 416 pp.

KleteČKa Z. \& Kollar D. 2003: Distribution of the beetles of the subfamilies Valginae and Trichiinae (Coleoptera, Scarabaeidae) in southern Bohemia. Acta Mus. Bohem. Meridion. České Budějovice (Sci. Nat.) 43: 79-92.

KonviČKa M. \& BenEš J. 2005: Condition and changes in biodiversity of day-butterflies. In Vačkář D. (ed.): Indicators of Changes in Biodiversity. Academia, Praha, pp. 116-126 [in Czech].

KuBISZ D. 2004: Zgniotek cynobrowy (Cucujus cinnaberinus). In Adamski P., Bartel R., Bereszyński A., Kepel A. \& Witkowski Z. (eds): Species of Animals (excl. Birds). Appendices for Conservation of Habitats and Species in Natura $2000-a$ Guide-Book. Ministerstwo Środowiska (Ministry of Environment), Warszawa, pp. 88-90 [in Polish].

LEGENDRE P. 1993: Spatial autocorrelation: trouble or new paradigm? Ecology 74: 1659-1673.

Lindenmayer D.B., Foster D., Franklin J.F., Hunter M., Noss R., Schiemegelow F. \& Perry D. 2004: Salvage harvesting after natural disturbance. Science 303: 1303.

LindHe A. \& Lindelöw Å. 2004: Cut high stumps of spruce, birch, aspen and oak as breeding substrates for saproxylic beetles. Forest Ecol. Manag. 203: 1-20.

Mamaev I.M., Krivosheina V.A. \& Pototskaya V.A. 1977: A Key to Larvae of Invertebrates Foraging on Insects. Nauka, Moskva, 392 pp. [in Russian].

Michalski F. \& Peres C.A. 2007: Disturbance-mediated mammal persistence and abundance-area relationships in Amazonian forest fragments. Conserv. Biol. 21: 1626-1640.

Mocek B. 2007: Flat bark beetle (Cucujus cinaberinus) (Coleoptera: Cucujidae) in East Bohemia (Czech Republic). Acta Mus. Reginaehrad. (A, Sci. Nat.) 32: 99-117.

Palm T. 1941: Über die Entwicklung und Lebensweise einiger wenig bekannten Käfer-Arten im Urwaldgebiet am Fluss Dalälven (Schweden) II und III. Opusc. Entomol. 6: 17-26.

PawŁowski J., Kubisz D. \& Mazur M. 2002: Coleoptera chrząszcze. In Głowaciński Z. (ed.): Red-List of Extinct and Endangered Animals. Instytut Ochrony Przyrody PAN (Department of Nature Conservation PAS), Kraków, pp. 88-110 [in Polish].

Pirnat A. \& Drovenik B. 2004: Natura 2000 - Beetles. Proteus 67: 79-88 [in Slovene, English abstr.].

Ranius T. 2001: Constancy and asynchrony of Osmoderma eremita in tree hollows. Oecologia 126: 208-215.

Ranius T., Aguado L.O., Antonsson K., Audisio P., Ballerio A., Carpaneto G.M., Сhobot K., Guurašin B., Hanssen O., Huijbregts H., Lakatos F., Martin O., Neculiseanu Z., Nikitsky N.B., Paill W., Pirnat A., Rizun V., Ruicanescu A., Stergner J., Süda I., Szwalko P., Tamutis V., Telnov D., Tsinkevitch V., Vignon V., Verstreirt V., Vögeli M. \& Zach
P. 2005: Osmoderma eremita (Coleoptera, Scarabeidae, Cetoniinae) in Europe. Anim. Biodiv. Conserv. 28: 1-44.

Rassi P., Alanen A., Kanerva T. \& Mannerkoski I. 2001: The Redlist of Finnish Species 2000. Ympäristöministeriö \& Suomen ympäristökeskus, Helsinki, 432 pp. [in Finnish, English abstr.].

Roubal J. 1936: Catalogue of Beetles of Slovakia and Transcarpatian Ukraine. Vol. II. Práce Učené Společnosti Šafaříkovy (Works of the Šafařík's Learned Society), Bratislava, 434 pp. [in Czech with French introduction].

SchlaghamerskÝ J., MaŇák V. \& Čechovský P. 2008: On the mass occurence of two rare saproxylic beetles, Cucujus cinnaberinus (Cucujidae) and Dircaea australis (Melandryidae), in South Moravian Floodplain Forests. Rev. Écol. (Suppl.) 10: 115-121.

Scopoli J.A. 1763: Entomologia Carniolica exhibens insecta Carnioliae indigena et distributa in ordines, genera, species, varietates. Methodo Linneana. J.T. Trattner, Vindobona, 420 pp.

Sittonen J. \& MartiKainen P. 1994: Occurrence of rare and threatened insects living on decaying Populus tremula: A comparison between Finnish and Russian Karelia. Scand. J. Forest Res. 9: 185-191.

Siitonen J. \& SaAristo L. 2000: Habitat requirements and conservation of Pytho kolwensis a beetle species of old-growth boreal forest. Biol. Conserv. 94: 211-220.

SpeIGHT M.C.D. 1989: Saproxylic Invertebrates and their Conservation. Council of Europe, Strasbourg, $81 \mathrm{pp}$.

Spitzer L., Konvicka M., Benes J., Tropek R., Tuf I.H. \& Tufova J. 2008: Does closure of traditionally managed open woodlands threaten epigeic invertebrates? Effects of coppicing and high deer densities. Biol. Conserv. 141: 827-837.

SüDA I. \& Voolma K. 2005: Conservation of beetles (Coleoptera) in Estonia. In Sklodowski J., Huruk S., Barsevskis A. \& Tarasiuk S. (eds): Protection of Coleoptera in the Baltic Sea Region: Fifth Symposium of Baltic Sea Coleopterologists, Poland, September 2004. Warsaw Agricultural University Press, Warsaw, pp. 47-56.

Sverdrup-Thygeson A. \& Ims R.A. 2002: The effect of forest clearcutting in Norway on the community of saproxylic beetles on aspen. Biol. Conserv. 106: 347-357.

ŠTernBergs M. 1998: Cucujus cinnaberinus (Scopoli, 1763). In Spuris Z. (ed.): Red Data Book of Latvija. Vol. 4. Invertebrates. Institute of Biology, University of Latvia, Riga, pp. 76-77.

VodKa S., Konvicka M. \& CizeK L. 2009: Habitat preferences of oak-feeding xylophagous beetles in a temperate woodland: implications for forest history and management. J. Insect Conserv. 13: 553-562.

WiezIK M., SvitoK M. \& DovČIAK M. 2007: Conifer introductions decrease richness and alter composition of litterdwelling beetles (Coleoptera) in Carpathian oak forests. Forest Ecol. Manag. 247: 61-71.

Received May 5, 2009; revised and accepted September 24, 2009 